\title{
PSYCHOLOGICAL STUDIES AND ACTIVITIES IN MARKETING RESEARCH
}

\author{
MINORU MAKITA \& HIROSHI KANEKO \\ Japan Social Research Institute \& Waseda University
}

Study of industrial psychology in Japan has, as has been reviewed by Dr. Kirihara in this journal, a fairly long history. ${ }^{1)}$ In the pre-war period, however, the industrial psychology was almost limited to the study of operation efficiency or of fatigue, in other words, limited to the field of Personnel Psychology. Accordingly, it was after the war that psychological studies and activities in the Marketing Research were taken up. We consider the following three conditions which have enabled the new development in the marketing research in Japan:

(I) Psychologists have mastered the techniques of sampling method and interviewing method for the social survey, and made these techniques developed. ${ }^{2)}$

(II) Research institutes and network for the survey have been organized for conducting public opinion poll and marketing research, applying above mentioned techniques. ${ }^{3}$ )

(III) Along with the prosperous conditions of the industry in the last few years, demands and interests in the scientific marketing research have been brought about in various fields of industry. 4 $^{\text {) }}$

It was a sort of fashion right after the war that newspapers or publishers of magazines often conducted various public opinion polls for the articles of their publications. Most of these surveys, however, were executed with imperfect methods and techniques. In 1946, Yoron Kagaku Kyokai (Y.K.K. Japan Social Research Institute) was organized by the authors, some other social psychologists, and a few sociologists and mathematicians. This institute has begun to hold periodical meeting for the study of scientific methods of social research, and to execute the actual survey with which one could study the actual way of it.

In 1951, Japanese Government established the National Public Opinion Survey Bureau. Dr. T. Takagi and other psychologists in various universities took part in this Bureau as the

1) S. Kirihara: "Industrial psycholog y in Japan." Psychologia, 1959, 2, 206-215.

2) Following books were written by psychologists:

S. Takagi: Research Method of Psychology, Tokyo: Iwanami Shoten, 1958

S. Takagi: Study of Quantification in Psychology, Tokyo: Univ. of Tokyo Press, 1954

H. Hidaka \& Others: Method of Social Survey, Tokyo: Seishin Shobo, 1955

N. Horikawa: Psychology and Techniques of Interview, 1953.

3) Following organizations are the marketing research organization to which psychologists are contributing: Yoron Kagaku Kyol:ai (Y.K.K. Japan Social Research Institute)

Marketing Center Co., Ltd.

Dentsu Co.

Central Research Services, Inc.

Social Psychology Institute

4) Y.K.K. has done about 1000 cases of research in the past 14 years (including both marketing research and puplic opinion survey). During the last one year, Marketing Center has conducted about 150 cases of research, requested from various clients. Annual amount of sales in average: $\$ 140,000$ in Y.K.K. and $\$ 200,000$ in Marketing Center. 
members of committee, and young psychologists worked there as full-time staffs. This governmental institute had not made a remarkable development, and was abolished in 1954. Some of the staffs in the Bureau established the Central Research Services, Inc. which was not a governmental and chiefly engaged in the marketing research. They are still doing their business.

At that time, Mr. H. Passin and Mr. J. Thayer who were working in the Cultural Division of C.I.E. (an office of U.S. Occupation Army in Japan) introduced experiences and techniques of the social survey in the U.S.A., and also, Dr. E. Demming of U.S. Census Bureau visited Japan in 1947 and in 1949. He greatly contributed to the development of new knowledges and techniques of sampling method, etc. In 1948, Japan Public Opinion Association was founded by the members of some research institutes, research sections of the newspaper companies and advertising agencies.

The development of psychological activities in marketing research has had some influences on the business and industry in Japan. Some enterprises began to employ university graduates who majored in psychology, as the staffs of their marketing research divisions. Also, some advertising agencies, such as Dentsu, began to employ psychologists. Before the marketing research was so prevailed, psychologists had been working only in the personnel management sections in some firms. But now, considerable number of psychologists are working in the Marketing and Sales Division of various firms.

Y.K.K. (Japan Social Research Institute), as has been mentioned before, had been chiefly engaged in the psychological studies concerning marketing research. However, demands for marketing survey from various firms have increased more and more. In order to deal with these business demands for Y.K.K., it was required to establish another organization which would specially engage in the contract survey. So, Marketing Center Company, Ltd. has been newly founded, besides Y.K.K. in 1959.

Generally speaking, the psychology divisions of universities in Japan have not yet been so active in the study of marketing. They have no course of lecture on marketing research. However, the fact that many firms are increasingly interested in the university graduates of psychology has been giving universities a serious impact.

Besides the research conducted by its own staff, Y.K.K. are getting cooperation with universities for basic study. Y.K.K. has recently asked Tokyo University an experiment on Subliminal Perception 5) and Waseda University on Motivation Research. ${ }^{6)}$

Concerning motivation research, Marketing Center, based on the long experience in Y.K.K. has begun to conduct it actually for the client since last year. Many industries in Japan are quite interested in the motivation research. The motivation research done by Marketing Center is chiefly based on the depth interview method. The groups of interviewers of Marketing Center are organized with teaching staffs of social and clinical psychology in every university in Japan. So, Marketing Center has nationwide network of interviewers. As for the

5) M. Sagara \& others. "A basic study on the subliminal perception," The Marketing Research, 1958, No. 69 and No. 70.

6) Y. Togawa \& others. "A study of projective test for motivation research, The Marketing Research, 1957, No. 65, 2-19. 
methods and techniques of the motivation research done by Marketing Center, as has been mentioned above, depth interview is the main method and various projective tests are also used as supplemental. Semantic Differential Method has recently been applied as one of the supplemental techniques. ${ }^{7)}$

There are still few books on psychological study of marketing research. ${ }^{8}$ ) Shinrigaku Kenkyu (Japanese Journal of Psychology), published by Japanese Association of Psychology has never had any articles on marketing research. Business journals sometimes carry the report about this subject. Shijo Chosa (The Marketing Research), published by Y.K.K., is the only magazine on marketing research run by psychologists.

$$
\text { MS. received, XI 19,60. }
$$

Minoru Makita（牧 田稔 1919- ) graduated from Univ. of Tokyo, Dept. of Psychol., in 1942; 194245, Researcher, Naval Inst. of Tech.; 1946- Director, Japan Social Research Inst.; 1959- Director, Marketing Center Co.; Lecturer, Waseda Univ. \& Meiji Univ.

Hiroshi Kaneko (兼子 宙 1909- ) graduated from Univ. of Tokyo, Dept. of Psychol., in 1931; 1932-45, Researcher, Naval Inst. of Tech.; 1946-48, Researcher, Ministry of Labor; 1949-52, Bureau chief, National Personnel Authority; 1953-58, Prof., Hiroshima Univ.; 1959- Prof., Waseda Univ.; Board of Directors, Japan Social Research Inst. \& Marketing Center Co.

7) "Semantic Differential Test for Motivation Research," The Marketing Research, 1960, No. 81.

8) M. Makita \& Y. Togawa: "Marke'ing," In the Series of Psychology of Business, No. 3, Tokyo: Chikuma Shobo, 1959.

Carol H. Ammons (1927- ) BA 1947; MA 1949, Tulane Univ.; PhD 1954, Univ. of Kentucky. 1949-, Southern Univ. Press, Montana State Univ. Editor, Psychological Reports and Perceptual and Motor Skills.

Robert B. Ammons (1920- ) BA 1939; MA 1941, PhD 1946, State Univ. of Iowa. 1950-, Southern Univ. Press, Montana State Univ. 1957-, Professor, Montana State Univ. Editor, Psychological Reports and Perceptual and Motor Skills. 